7-1-1994

\title{
Prostitutes in the archives: Problems and possibilities in documenting the history of sexuality
}

Timothy J. Gilfoyle

Loyola University Chicago, tgilfoy@luc.edu

Follow this and additional works at: https://ecommons.luc.edu/history_facpubs

Part of the History Commons

\section{Recommended Citation}

Gilfoyle, Timothy J.. Prostitutes in the archives: Problems and possibilities in documenting the history of sexuality. The American Archivist, 57, 3: 514-527, 1994. Retrieved from Loyola eCommons, History: Faculty Publications and Other Works, http://dx.doi.org/10.17723/aarc.57.3.p74tr646p6r530lv

This Article is brought to you for free and open access by the Faculty Publications and Other Works by Department at Loyola eCommons. It has been accepted for inclusion in History: Faculty Publications and Other Works by an authorized administrator of Loyola eCommons. For more information, please contact ecommons@luc.edu. (c) (1) $(9)$

This work is licensed under a Creative Commons Attribution-Noncommercial-No Derivative Works 3.0 License. (c) The American Archivist, 1994. 


\title{
Perspective
}

\section{Prostitutes in the Archives: Problems and Possibilities in Documenting the History of Sexuality}

\author{
TIMOTHY J. GILFOYLE
}

\begin{abstract}
In the past decade, the study of sexuality has proven to be one of the most dynamic academic enterprises. Among the most popular topics has been the history of prostitution. Archivists have been invaluable but largely unsung allies in the explosive growth of a new revisionist literature. Through the preservation of long-ignored and oftendiscarded records and manuscripts, archivists provided the means enabling historians to answer many new questions, not only about prostitution but about the history of sexuality. Yet some of these sources raise provocative and controversial problems for historians and archivists documenting the history of sexuality. The author acknowledges and thanks Loyola University of Chicago, the National Endowment for the Humanities, and the Newberry Library in Chicago for providing financial support to complete this article. His appreciation also extends to Mary Rose Alexander, Kenneth Cobb, Phillip Costello, and the anonymous referees of The American Archivist for their criticism and helpful comments on earlier drafts.
\end{abstract}

About the author: Timothy J. Gilfoyle is the author of City of Eros: New York City, Prostitution, and the Commercialization of Sex, 1790-1920 (W.W. Norton, 1992), which was the recipient of the Allan Nevins Prize of the Society of American Historians and the New York State Historical Association Manuscript Prize. His articles have been published in the American Quarterly, Journal of Urban History, Seaport Magazine, and Missouri Review. Gilfoyle received his Ph.D. in American history from Columbia University in 1987; he is an assistant professor of history at Loyola University of Chicago and an N.E.H./Lloyd Lewis Fellow at the Newberry Library. 
THE STUDY OF SEXUALITY is currently one of the most dynamic academic enterprises, and examples of intellectual fertility in this area abound. New peer-review publications, such as the Journal of the History of Sexuality, are on the cutting edge in social history research. A diversity of institutions, including Yale University, City University of New York, and San Francisco State University, are among the first to establish gay and lesbian studies programs in the United States. Publications by Michel Foucault, John D'Emilio, Estelle Freedman, Peter Gay, and Thomas Laqueur not only have reinterpreted the history of sexual behavior but have also significantly influenced scholarship in cultural studies, literature, and philosophy. ${ }^{1}$ Some will remain standard accounts into the next century. So daunting is the outpouring of monographic literature that it is almost impossible to keep abreast of the field.

Prostitution is one of the most popular topics in this literary outburst. Nearly a score of book-length histories on the subject have appeared in slightly more than a decade. ${ }^{2}$ More voluminous is the bounty of

\footnotetext{
${ }^{1}$ Michel Foucault, The History of Sexuality: Volume 1, An Introduction, translated by Robert Hurley (New York: Pantheon, 1978); John D'Emilio and Estelle Freedman, Intimate Matters: A History of Sexuality in America (New York: Harper and Row, 1988); Peter Gay, The Bourgeois Experience, Victoria to Freud, 2 vols. (New York: Oxford University Press, 1984-86); Thomas Laqueur, Making Sex: Body and Gender from the Greeks to Freud (Cambridge, Mass.: Harvard University Press, 1990).

${ }^{2}$ Jacqueline Baker Barnhart, The Fair But Frail: Prostitution in San Francisco, 1849-1900 (Reno: University of Nevada Press, 1986); Anne M. Butler, Daughters of Joy, Sisters of Misery: Prostitutes in the American West, 1865-1890 (Urbana: University of Illinois Press, 1985); Mark Thomas Connelly, The Response to Prostitution in the Progressive Era (Chapel Hill: University of North Carolina Press, 1980); Alain Corbin, Women for Hire: Prostitution and Sexuality in France After 1850 (Cambridge, Mass.: Harvard University Press, 1990) [orig. Les Filles de Noce: Misère Sexuelle et Prostitution au 19e et 20e Siécles (Paris: Aubier Montaigne, 1978)]; Frances Finnegan, Poverty and Prostitution: A Study of Victorian Prostitutes in York (Cambridge: Cambridge University
}

articles. $^{3}$ Indeed, it is now possible to de-

Press, 1979); Mary Gibson, Prostitution and the State in Italy, 1860-1915 (New Brunswick, N.J.: Rutgers University Press, 1986); Timothy J. Gilfoyle, City of Eros: New York City, Prostitution, and the Commercialization of Sex, 1790-1920 (New York: W.W. Norton, 1992); Marion S. Goldman, Gold Diggers and Silver Miners: Prostitution and Social Life on the Comstock Lode (Ann Arbor: University of Michigan Press, 1981); Donna J. Guy, Sex and Danger in Buenos Aires: Prostitution, Family, and Nation in Argentina (Lincoln, Neb.: University of Nebraska Press, 1991); Jill Harsin, Policing Prostitution in Nineteenth-Century Paris (Princeton, N.J.: Princeton University Press, 1985); Marilynn Wood Hill, Their Sisters' Keepers: Prostitution in New York City, 1830-1870 (Berkeley: University of California Press, 1993); Barbara Meil Hobson, Uneasy Virtue: The Politics of Prostitution and the American Reform Tradition (New York: Basic Books, 1987); Thomas C. Mackey, Red Lights Out: A Legal History of Prostitution, Disorderly Houses, and Vice Districts, 1870 1917 (New York: Garland, 1987); Leah L. Otis, Prostitution in Medieval Society: The History of an Urban Institution in Languedoc (Chicago: University of Chicago Press, 1985); Ruth Rosen, The Lost Sisterhood: Prostitution in America, 1900-1918 (Baltimore: Johns Hopkins University Press, 1982); Christine Stansell, City of Women: Sex and Class in New York, 1789-1860 (New York: Alfred Knopf, 1986); Richard Symanski, The Immoral Landscape: Female Prostitution in Western Societies (Toronto: Butterworths, 1981); Judith Walkowitz, Prostitution and Victorian Society: Women, Class, and the State (Cambridge: Cambridge University Press, 1980). For an example in a European colony, see Luise White, The Comforts of Home: Prostitution in Colonial Nairobi (Chicago: University of Chicago Press, 1990).

${ }^{3}$ Jeffrey S. Adler, "Streetwalkers, Degraded Outcasts, and Good-for-Nothing Huzzies: Women and the Dangerous Class in Antebellum St. Louis," Journal of Social History 25 (Summer 1992): 737-56; Joel Best, "Business Is Business: Regulating Brothel Prostitution Through Arrests, St. Paul, 1865-1883,' Social Policy 1 (Spring 1987): 1-20; "Keeping the Peace in St. Paul: Crime, Vice and Police Work, 1869-74,' Minnesota History 47 (Summer 1981): 240-48; "Careers in Brothel Prostitution: St. Paul, 1865-1883,' Journal of Interdisciplinary History 12 (Spring 1982): 597-619; George M. Blackburn and Sherman L. Ricards, "The Prostitutes and Gamblers of Virginia City, Nevada: 1870,' Pacific Historical Review 48 (May 1979): 239-58; Patricia Cline Cohen, "The Helen Jewett Murder: Violence, Gender, and Sexual Licentiousness in Antebellum America," $\mathrm{Na}$ tional Women's Studies Association Journal 2 (Summer 1990): 374-89; Richard J. Evans, "Prostitution, State, and Society in Imperial Germany," Past and Present 70 (February 1976): 106-29; Claudia D. Johnson, "That Guilty Third Tier: Prostitution in Nineteenth-Century American Theaters," American 
vise and organize undergraduate and graduate history courses with lengthy and complex syllabi devoted strictly to the history of prostitution.

Archivists were invaluable but largely unsung allies in the explosive surge in this literature. Through the preservation of long-ignored and often-discarded records and manuscripts, archivists provided the vehicle for social historians to answer many new questions about prostitution and, consequently, about the history of sexuality. Yet some of these sources raise provocative and difficult problems for historians and archivists alike. Equally significant, these questions, although they are immediately concerned with prostitution, also reflect vital issues for researchers and archivists studying the history of sexuality.

Prostitution has attracted the interest of recent social historians for a number of reasons. While some investigations offer distinctive interpretations, certain themes prevail. Most argue or imply that commercial sex functioned at the nexus of social

Quarterly 27 (December 1975): 575-84; Ivan Light, "From Vice District to Tourist Attraction: The Moral Career of American Chinatowns, 1880-1940," Pacific Historical Review 43 (August 1974): 367-94; James R. McGovern, “'Sporting Life on the Line': Prostitution in Progressive Era Pensacola," Florida Historical Quarterly 54 (October 1975): 131-42; Mary Elizabeth Perry, " "Lost Women' in Early Modern Seville: The Politics of Prostitution," Feminist Studies 4 (Spring 1978): 195-211; Paula Petrick, "Capitalists with Rooms: Prostitution in Helena, Montana, 1865-1900," Montana 31 (April 1981), 28-41; David J. Pivar, "Cleansing the Nation: The War on Prostitution, 1917-21," Prologue 12 (Spring 1980): 29-40; Steven Ruggles, "Fallen Women: The Inmates of the Magdalen Society Asylum of Philadelphia, 1836-1908," Journal of Social History 16 (Summer 1983): 65-82; Neil Larry Shumsky, "Tacit Acceptance: Respectable Americans and Segregated Prostitution, 1870-1910," Journal of Social History 19 (Summer 1986): 665-79; Neil Larry Shumsky and Larry M. Springer, “San Francisco's Zone of Prostitution, 1880-1934," Journal of Historical Geography 7 (January 1981): 71-89; Richard Tansey, "Prostitution and Politics in Antebellum New Orleans,"' Southern Studies 18 (Winter 1979): 449-79. relations in community life, especially in the industrial city after 1800 . Prostitution embodied more than sexual behavior. Definitions of crime, the status of women, new forms of economic development, changing gender relations, the use of urban real estate, the application of modern theories of health care, the rise of popular entertainment, and the appearance of alternative subcultures were directly linked to commercial sex. In ambiguous, paradoxical, and controversial ways, prostitution represented a critical, ongoing conflict between individual freedom and community norms.

Scholarly interest in the history of sexuality is also a practical reflection of the increasing prominence and discussion of sexual matters in American life. At the center of these conflicts is a little-recognized debate over the very way most Americans understand and comprehend their sexuality, which ultimately influences how scholars and archivists preserve past records. Before the publication of Alfred Kinsey's studies on American sexual behavior, a near-consensus reigned. (Anthropology was the singular exception to this consensus.) Intellectuals and the public considered sexuality to be the subject of biology and the natural sciences. Generally, both groups believed that sexual behavior was a biological given, uniform across the species and, indeed, most forms of animal life. It was an "essential" part of human nature. ${ }^{4}$ Even though Kinsey's work challenged this assumption, his academic training in zoology and the scientific method he employed reinforced the "biological" paradigm of sexuality. This "essentialist" interpretation of

${ }^{4}$ Alfred E. Kinsey, Wardell B. Pomeroy, and Clyde E. Martin, Sexual Behavior in the Human Male (Philadelphia: W.B. Saunders, 1948); Sexual Behavior in the Human Female (Philadelphia: W.B. Saunders, 1953). 
sexual behavior still prevails among large numbers, if not a majority, of Americans. ${ }^{5}$

Few social historians, however, believe this today. The definition of sexuality has changed among those who study sexual behavior. For them, sexuality is a social construct, something shaped more by the environment and social circumstances than by heredity. No longer does the word imply just physical sexual behavior or biological reproduction; rather, it now includes the broader terms and conditions under which physical intimacy occurs and the outward expressions and manifestations of such behavior.6 Michel Foucault argues that sexuality "must not be thought of as a kind of natural given which power tries to hold in check, or as an obscure domain which knowledge tries gradually to uncover. It is the name that can be given to a historical construct: not a furtive reality that is difficult to grasp, but a great surface network in which the stimulation of bodies, the intensification of pleasures, the incitement of discourse, the formation of special knowledges, the strengthening of controls and resistances, are linked to one another." 7 In effect, the history of sexuality embodies cultural history.

Even among "social constructionists" prostitution remains a source of conflict and controversy. A sometimes-fierce debate, for example, divides feminists on whether to regard prostitutes as ordinary wage laborers seeking better wages, treatment, and working conditions, or as petty entrepreneurs whose work benefits a mi-

${ }^{5}$ Although I have no quantitative evidence to support this, after a decade of teaching college-level classes in the subject, my qualitative experience confirms such a conclusion.

${ }^{6}$ For more on this debate, see the articles by John Boswell, David M. Halperin, and Robert Padgug in Hidden from the Past: Reclaiming the Gay and Lesbian Past, edited by Martin Duberman, Martha Vicinus, and George Chauncey, Jr., (New York: New American Library, 1989), 17-66.

${ }^{7}$ Foucault, History of Sexuality, 105-06. nority at the expense of degrading a larger body of women. ${ }^{8}$ Still others are torn over the issues of structuralism and individual agency. Were prostitutes entirely victims of male violence, social control, or state suppression (and thus little able to control their destiny)? Or did such women retain in their everyday life a degree of personal agency that neutralized the impact of these larger (and seemingly uncontrollable) structural forces? ${ }^{9}$

These and similar questions have transformed the historiography of prostitution. Contrary to popular perception, there were more than a few books on prostitution prior to 1980 , but these studies suffered from considerable weaknesses. The most popular emphasized the more salacious aspects of the subject. ${ }^{10}$ The most scholarly focused less on prostitution and more on reform efforts to eliminate it or on governmental programs to control it. ${ }^{11}$

\footnotetext{
8Judy Coffin, "Artisans of the Sidewalk," Radical History Review 26 (October 1982): 89-101.

${ }^{9}$ For a brief discussion of this, see White, Comforts of Home, 5-12.

${ }^{10}$ Curt Gentry, The Madams of San Francisco (Garden City, N.Y.: Doubleday, 1964); James R. Gray, Red Lights on the Prairies (Toronto: Macmillan of Canada, 1971); Douglas McDonald, The Legend of Julia Bulette and the Red Light Ladies of Nevada (Las Vegas: Nevada Publications, 1980).

${ }^{11}$ Roy Lubove, "The Progressive and the Prostitute," The Historian 24 (May 1962): 308-30; Egal Feldman, "Prostitution, the Alien Woman, and the Progressive Imagination, 1910-1915," American Quarterly 19 (Summer 1967): 192-206; Robert E. Riegel, "Changing American Attitudes Toward Prostitution, 1800-1920," Journal of the History of Ideas 29 (July-September 1968): 437-52; Charles Winick and Paul M. Kensie, The Lively Commerce: Prostitution in the United States (Chicago: Quadrangle Books, 1971); Carroll Smith-Rosenberg, "Beauty, the Beast, and the Militant Woman," American Quarterly 23 (October 1971): 562-84; David J. Pivar, Purity Crusade: Sexual Morality and Social Control, 18691900 (Westport, Conn.: Greenwood, 1973), and "Cleansing the Nation"; Evans, "Prostitution, State, and Society in Imperial Germany;" James Wunsch, "Prostitution and Public Policy: From Regulation to Suppression, 1858-1920" Ph.D. diss., University of Chicago, 1976; Larry Howard Whiteaker, "Moral Reform and Prostitution in New York City, 1830 1860,' Ph.D. diss., Princeton University, 1977; Con-
} 
Studies of prostitution itself, such as Vern Bullough's The History of Prostitution (1975), Fernando Henriques's Prostitution and Society (1962), and Richard Symanski's The Immoral Landscape (1981), examined cities with red-light districts, thus emphasizing the most visible and elite forms of prostitution. These accounts relied largely on published primary and secondary sources. Few writers ever ventured into an archive. ${ }^{12}$ Limited in their research, these studies rarely attended to the lives of prostitutes themselves, nor did they examine the larger cultural framework within which the institution and practice flourished. ${ }^{13}$

\section{Social History, the New Views of Sexuality, and New Uses of Archives}

The new social history changed this. Beginning with European studies such as Alain Corbin's Women for Hire [originally Les Filles de Noce] (1978), Frances Finnegan's Poverty and Prostitution (1979), and Judith Walkowitz's Prostitution and Victorian Society (1980), historians ap-

nelly, Response to Prostitution; Edward J. Bristow, Prostitution and Prejudice: The Jewish Fight Against White Slavery, 1870-1939 (Oxford: Clarendon, 1982); Marcia Roberta Carlisle, "Prostitutes and Their Reformers in Nineteenth-Century Philadelphia," Ph.D. diss., Rutgers University, 1982; Hobson, Uneasy Virtue; Mackey, Red Lights Out; Tansey, "Prostitution and Politics."

${ }^{12}$ Fernando Henriques, Prostitution and Society, 2 vols. (New York: Citadel Press, 1962 and 1963); Al Rose, Storyville, New Orleans (University, Ala.: University of Alabama Press, 1974); Light, "From Vice District to Tourist Attraction"; McGovern, “' 'Sporting Life on the Line' "'; Vern L. Bullough, The History of Prostitution (New Hyde Park, N.Y.: University Books, 1964); Vern L. Bullough and Bonnie Bullough, Prostitution: An Illustrated Social History (New York: Crown, 1978), revised as Women and Prostitution: A Social History (Buffalo: Prometheus Books, 1987); Blackburn and Ricards, "The Prostitutes and Gamblers of Virginia City, Nevada: 1870"'; Symanski, The Immoral Landscape; Shumsky, "Tacit Acceptance"; Shumsky and Springer, "San Francisco's Zone of Prostitution."

${ }^{13}$ For a critique of this earlier literature, see Best, "Careers in Brothel Prostitution: St. Paul.," proached the subject with both new questions and innovative and untried methods. The Europeanists were quickly followed on the other side of the Atlantic by Ruth Rosen's The Lost Sisterhood (1982), Anne Butler's Daughters of Joy, Sisters of Misery (1985), and Christine Stansell's City of Women (1986). The bulk of this research centered on the period between 1800 and 1920. While working separately, these historians shared a collective intellectual enterprise, engaging in some of the most detailed and rigorous detective work, searching for new archival sources, and finding previously ignored materials. ${ }^{14}$

European historians enjoyed certain advantages in this enterprise. Prostitution in Europe was a sexual activity whose boundaries were frequently controlled and defined by the state. Intermittent periods of legalization and regulation produced a unique and considerable body of government records. ${ }^{15}$ Specifically, data from the files of police forces and law enforcement agencies enabled European historians to examine the employment history, family background, marital status, and medical history of prostitutes. American historians had no such benefit in their search for new sources. ${ }^{16}$

${ }^{14}$ For an insightful examination of this methodology, see Susan Grigg, "Archival Practice and the Foundations of Historical Method," Journal of American History 78 (1991): 228-39.

${ }^{15}$ Especially see Corbin, Women for Hire; Walkowitz, Prostitution and Victorian Society, 3.

${ }^{16} \mathrm{On}$ a rare case of legalization in the United States, see Duane R. Sneddeker, "Regulating Vice: Prostitution and the St. Louis Social Evil Ordinance, 18701874,"' Gateway Heritage, 11 (Fall 1990): 20-47; John C. Burnham, "Medical Inspection of Prostitutes in the Nineteenth Century: The St. Louis Experiment and Its Sequel,' Bulletin of the History of Medicine, 45 (May-June 1971), 203-18; “"The Social Evil Ordinance-A Social Experiment in Nineteenth-Century St. Louis,' Bulletin of the Missouri Historical Society 27 (April 1971): 203-17. From 1898 to 1917, the city of New Orleans prohibited prostitution outside a small, defined neighborhood that became known as Storyville. Municipal and other records concerning the district appear to have been destroyed or dis- 
Government archival sources have been critical to this revisionist paradigm. More than any other topic examined by recent historians of sexuality, the study of prostitution requires manuscript court records. In particular, two types of court records are most common in local communities: first, arrests and indictments brought before police or magistrates' courts, and second, jury trials. The former occupied the lowest level of the municipal court system and, consequently, the first layer in the urban legal process. By the mid-nineteenth century, large cities usually had several of these decentralized judicial bodies. Legal decisions frequently were made by trial judges, some of whom did not even possess law degrees. ${ }^{17}$

Many of these records were discarded because later municipal officials considered them unimportant. Most incidents concerned petty crimes, especially drunkenness and disorderly conduct, convincing myriad local officials that these documents were unworthy of preservation. Numerous cases undoubtedly involved prostitution. Even in some cities (e.g., New York) where a significant quantity of these records survived, they remained unknown, unexplored, and fragmentary as late as 1979..$^{18}$ Furthermore, these manuscripts

carded. See Rose, Storyville, 1-15. For a useful introduction to finding sources in women's history, see Laurel Thatcher Ulrich, "Of Pen and Needles: Sources in Early American Women's History," Journal of American History 77 (June 1990): 20007.

${ }^{17}$ For critiques of the police court system, see Edward Crapsey, The Nether Side of New York (New York: Sheldon, 1872); New York Times, 26 June 1895, in District Attorney Scrapbook, vol. 142, New York City Municipal Archives and Records Center (hereafter NYCMA).

${ }^{18}$ Prior to the organization of the NYCMA in the late $1970 \mathrm{~s}$, American historians believed that all nineteenth-century arrest blotters in New York City had been destroyed. See Eric Monkkonen, "Systematic Criminal Justice History: Some Suggestions," Journal of Interdisciplinary History 9 (Winter 1979): 45164. Police court records for New York City are fragmentary. Docket books providing a summary record of every arrest from 1790 to 1962 have survived. were voluminous. By the 1870 s, for instance, over 80,000 people were appearing before the New York City police court justices annually, roughly one of every twelve citizens, or one of every eight or nine males. ${ }^{19}$

A second source of judicial records is the indictment records from jury trials in courts of general or quarter sessions. Although less voluminous than police court records, their number is often considerable. Other court-generated records that sometimes contain information on prostitutes include bastardy bonds and divorce proceedings. ${ }^{20}$ These record sets provide names of plaintiffs and defendants, sometimes their addresses, formal indictments, particulars regarding defendants' backgrounds, summaries of testimony, and final decisions. Although most nineteenth-century judicial cases lack the detailed investigations and internal memoranda common to their twentieth-century counterparts, such records remain one of the choice manuscript sources available to historians.

These records are of critical importance to historians of sexuality. Specifically, they offer one of the few unpublished manuscript records of human behavior in this area. Earlier work in the history of sexuality too often relied on published prescrip-

Some manuscript records for the years before 1860 still exist, but ones for later years appear have been lost or destroyed.

${ }^{19}$ In 1874, New York City police courts disposed of 84,839 cases $(60,231$ males and 24,608 females). A year later, the figure was $84,399(60,331$ males and 24,068 females). See Board of the Police Justices of the City of New York, Annual Report for 1875 (New York, 1876), 4; Third Annual Report for 1876 (New York, 1877), 3.

${ }^{20}$ In her limited discussion of prostitution in antebellum North Carolina, Victoria Bynum used criminal action papers, bastardy bonds, and divorce records, which were organized by county in the North Carolina Department of Archives and History in Raleigh. See Victoria Bynum, Unruly Women: The Politics of Social and Sexual Control in the Old South (Chapel Hill: University of North Carolina Press, 1992), chapter 4 . 
tive literature, usually because writers believed it represented the only available source. In contrast, indictments and other court records allow historians to examine social behavior that rarely appears in published documents. Such sources, for instance, uncover internal community conflicts. Before 1850 and the adoption of organized municipal police forces, most cases were initiated by ordinary citizens, not local prosecutors or municipal authorities. Indictments thus disclose how ordinary citizens reacted to certain forms of crime or perceived misbehavior. ${ }^{21}$

The importance of local prosecutions go beyond prostitution. Such documents offer an entry into a variety of unstudied sexual subcultures and topics. Sodomy indictments, for example, reveal the advent and possible formation of a male homosexual community. Bail bonds of arrested prostitutes can illustrate levels of community support or the networks of pimps. Libel suits against various newspaper editors mark the earliest attacks on obscenity and the beginnings of a pornography industry. Some of the first controversies concerning the role and frequency of abortion are documented by cases as early as the $1840 \mathrm{~s}^{22}$ Various aspects of the "underworld," even elements of "respectable" society, lay bur-

\footnotetext{
${ }^{21}$ Allen Steinberg, The Transformation of Criminal Justice: Philadelphia, 1800-1880 (Chapel Hill: University of North Carolina Press, 1989). For theoretical and practical problems on the use of court records in the study of crime, see "Introduction"; Bruce Lenman and Geoffrey Parker, "The State, the Community and the Criminal Law in Early Modern Europe", and J. A. Sharpe, "Enforcing the Law in the Seventeenth-Century English Village"'; all in Crime and the Law: The Social History of Crime in Western Europe since 1500 , edited by V. A. C. Gatrell, Bruce Lenman, and Geoffrey Parker (London: Europa Publications, 1980), 1-48; Gatrell and T. B. Hadden, "Criminal Statistics and Their Interpretation," in NineteenthCentury Society: Essays in the Use of Quantitative Methods for the Study of Social Data, edited by E. A. Wrigley (Cambridge: Cambridge University Press, 1972).

${ }^{22}$ For a brief introduction to these topics and sources, see Gilfoyle, City of Eros, 130-38, 367-70.
}

ied within these documents, awaiting their historian.

Records of a city mayor's office represent another previously ignored source. For a century, roughly from 1820 to 1920 , prostitution was both a social problem and a political problem in most American cities. On numerous occasions, it became an issue in electoral campaigns (in New York in 1886 and in St. Louis in 1874, for example). At other times, mayors used commercial sex, and their fight against it, as a lever to gain public approval. For still others, prostitution became a source of criticism or embarrassment; consider the New York mayoralties of Fernando Wood, W. R. Grace, or Jimmy Walker. ${ }^{23}$ Ordinary citizens frequently wrote to sympathetic mayors complaining about prostitutes. When Abram Hewitt was elected mayor of New York in 1886, for example, local residents wrote to him and specifically detailed the public displays of sexuality by prostitutes in their neighborhood, on their block, or even in their tenement. But such letters are not easily found, for they usually are filed with other complaints to the mayor regarding such issues as street obstructions, peddling, missing persons, or various city services. ${ }^{24}$

Equally significant, mayors' papers frequently include records destroyed by other municipal agencies. In New York, for example, the police department destroyed most of its arrest and manuscript records in 1914. ${ }^{25}$ Correspondence between mayors and police officials now preserved in the

\footnotetext{
${ }^{23}$ Gilfoyle, City of Eros, 127-28, 183-84, 192-97.

${ }^{24} \mathrm{See}$ the mayoral papers of Abram Hewitt, Hugh Grant, and William J. Gaynor, Boxes 87-HAS-28 to 87-HAS-34, 88-GHJ-38 to 88-GHJ-40, GWJ-17, GWJ-35, GWJ-37, and GWJ-56, NYCMA.

${ }^{25}$ James F. Richardson, The New York Police: Colonial Times to 1901 (New York: Oxford University Press, 1970), 291; Wilbur Miller, Cops and Bobbies: Police Authority in New York and London, 1830 1870 (Chicago: University of Chicago Press, 1973),
} 211. 
mayors' papers remain one of the few unpublished records of the nineteenth-century police.

Incarceration registers represent still another little-exploited source. Penitentiaries, houses of refuge, reformatories, and private asylums were new institutions in the nineteenth century and were the destination for convicted prostitutes. Entry ledgers from Magdalen asylums enabled one historian to describe the changing characteristics and social profile of nineteenth-century inmates. ${ }^{26}$ Because the poorest and least protected prostitutes are found in these records, they thus raise questions of their representational quality. Nevertheless, such documents remain the most useful in compiling a limited social profile of prostitutes.

Many recent studies of prostitution rely on the manuscript collections of various municipal reform organizations. Public prostitution frequently evoked considerable popular anger and outrage, resulting in organized efforts to eliminate it. Periodically, "female moral reform societies" in the antebellum years, "societies for the suppression of vice"' in the post-Civil War era, and even neighborhood community or block associations organized in opposition to prostitution. The Society for the Prevention of Cruelty to Children (SPCC) in New York, for example, founded in 1872, regularly corresponded with mayors regarding the public sexual activity and child theatrical performances (the two often were interchangeable) in concert saloons, beer gardens, and theaters. The mayor had final licensing power over such enterprises. The SPCC hired private investigators who visited these establishments, writing detailed accounts on what they observed.

After 1900, however, nearly every large city had its own "vice" society, many publishing periodic reports. Among them were the Committee of 15 (1900-02) and

\footnotetext{
${ }^{26}$ Ruggles, "Fallen Women.',
}

Committee of 14 (1905-32) in New York City; the Committee of 50 in Rockland County, New York (1915); the Committee of 18 in Syracuse (1913); the Public Welfare Council of Grand Rapids, Michigan (1913); and the Cleveland Baptist Brotherhood (1911). Their reports and those of vice commissions in cities as diverse as Atlanta, Georgia (1912); Chicago, Illinois (1911); Hartford, Connecticut (1913); Lafayette, Indiana (1913); Lancaster, Pennsylvania (1913); Little Rock, Arkansas (1913); Paducah, Kentucky (1916); Portland, Oregon (1913); and Shreveport, Louisiana (1915) exemplify this genre. ${ }^{27}$ Finally, individual reformers frequently left voluminous records concerning their work and observations on the subject. Among the most prominent are the Lillian Wald papers at Columbia University, the Harriet Laidlaw papers in the Schlesinger Library at Radcliffe College, and the Blackwell family papers at the Library of Congress.

Revisionist accounts of prostitution have not ignored published records. Local newspapers and numerous magazines frequently commented on vice commission and other reports, in particular such publications as Outlook, Current Opinion, Survey, Forum, McClure's, Collier's, and the Journal of Social Hygiene. Recently discovered "underground" newspapers provide more untapped material, particularly the antebellum "sporting" or "flash" newspapers. With such titles as the Whip, Libertine, Rake, and Flash, these weekly but short-lived periodicals provided all kinds of information, salacious and other, on prostitutes, their clients, living conditions, periodic balls and parties, and even sporting events. These publications are among the few nineteenth-

\footnotetext{
${ }^{27} \mathrm{~A}$ good bibliography for these and other similar studies is in Rosen, Lost Sisterhood.
} 
century records that mention "male prostitutes." 28

Even more useful than newspapers and magazines have been recently discovered guidebooks to brothels and similar establishments. Written to entertain as well as inform, such guidebooks were published in most large cities. Some employed satirical titles like The Gentleman's Companion (1870) in New York, or A Guide to the Stranger, or Pocket Companion for the Fancy, Containing a List of the Gay Houses and Ladies of Pleasure in the City of Brotherly Love and Sisterly Affections (1849) in Philadelphia. Still others had authors with such outrageous pseudonyms as "'Charles DeKock," "Free Loveyer," and "Butt Ender."'29

Records such as these were occasionally and selectively employed in earlier histor-

\footnotetext{
${ }^{28}$ Despite references to "male prostitutes," the term was very ambiguous and more often synonymous with heterosexual "sporting men" who consorted with prostitutes. For a discussion of this problem, see Gilfoyle, City of Eros, 369-70.

${ }^{29}$ Free Loveyer [sic], Directory to the Seraglios in New York, Philadelphia, Boston, and All the Principal Cities in the Union (New York: Printed and Published for the Trade, 1859); The Gentleman's Companion: New York City in 1870 (New York: 1870), both in the New-York Historical Society; Old Man of Twenty-five [Charles DeKock], Guide to the Harem; or, Directory to the Ladies of Fashion in New York and Various Other Large Cities (New York: Charles DeKock 1855 and 1856); Butt Ender, Prostitution Exposed; or, A Moral Reform Directory (New York: Butt Ender, 1839), all in the personal collection of Leo Hershkowitz, Queens College, City University of New York; A Guide to the Stranger, or Pocket Companion for the Fancy, Containing a List of the Gay Houses and Ladies of Pleasure in the City of Brotherly Love and Sisterly Affections (Philadelphia: publisher unknown, 1849), cited in Carlisle, "Prostitutes and Their Reformers," 51; Anonymous, The Green Book, or the Gentleman's Guide to New Orleans, Listing the Principal Maisons de Joie: Names of Madames, Angels, Nymphs, and Fairies, Color and $\mathrm{Na-}$ tionality (New Orleans: publisher unknown, 1895) and Blue Book (New Orleans: publisher unknown, $1900)$, cited in Rose, Storyville, 136-41, and Goldman, Gold Diggers, 187; William R. Gillis, The Nevada Directory for 1868-69 (San Francisco: M. D. Carr and Co., 1868), cited in Goldman, Gold Diggers, 189,205
}

ical accounts, but revisionists have used them in new and creative ways. For example, specific addresses of brothels and other locales of prostitution have allowed historians to approach manuscript censuses with different questions, usually providing a more accurate social profile of the prostitutes themselves. The same information has also enabled historians to search not only city directories but also tax assessment, estate, probate, and conveyance records, most of which are still used by municipal agencies. Historians employing these sources have contributed more detailed accounts of previously ignored property owners secretly involved in the underground economy. ${ }^{30}$

By intelligently combining these multiple sources, these studies dramatically revised-in some respects even revolutionized-'the historical treatment of prostitution. Archivists not only opened up new areas of research but also allowed historians to present a multilayered and nuanced treatment of the topic. The most recent work treats prostitution as a product of new economic, social, and cultural conditions, most often related to a changing labor market offering limited employment opportunities to women. These interpretations reveal not only the dynamics of commercial sex but also its geographical movement, clientele, sexual politics, supportive institutions, and even the relationship between property and prostitution. More important, these historians have rescued prostitution from the literature of deviancy

\footnotetext{
${ }^{30}$ See Gilfoyle, City of Eros, chapters 2 and 10; Bynum, Unruly Women, chapter 4. Census manuscripts, however, have proven less useful than with other subjects. Only in rare cases, particularly " frontier" communities, did prostitutes admit to their activity. In addition, prostitutes proved to be so transient that census enumerators frequently missed them. For examples of prostitutes found in census manuscripts, see Butler, Daughters of Joy, 160; Bynum, Unruly Women, 181; Gilfoyle, City of Eros, chapters 3 and 13; Goldman, Gold Diggers, 102-03, 206.
} 
and crime. Prostitutes are considered not "fallen women" but rather females who made rational and sometimes desperate choices when confronted with limited possibilities. Furthermore, we now know more both about the prostitutes themselves (something painfully lacking in the American literature before 1980) and about the culture and social conditions in which they lived and worked. Revisionist studies of prostitution have even influenced the standard narratives on American and women's history. Whereas earlier studies, like the societies they examined, marginalized prostitutes, recent historiography has integrated them into the larger historical narrative. ${ }^{31}$

\footnotetext{
${ }^{31}$ Examples of U.S. history textbooks with discussions of prostitution include Joseph R. Conlin, The American Past: A Survey of American History, 4th ed. (New York: Harcourt Brace Jovanovich, 1993), 384, 481, 495-96, 581-82, 625; Herbert Gutman et al., Who Built America? Working People and the Nation's Economy, Politics, Culture and Society (New York: Pantheon, 1989), vol. 1: 250, 284, 293, 306; vol. 2: 55-57, 513; Robert Kelley, The Shaping of the American Past (Englewood Cliffs, N.J.: Prentice-Hall, 1990), 430-31, 558, 560, 564, 575, 841. For examples in women's history texts, see Alice Kessler-Harris, Out to Work: A History of Wage-Earning Women in the United States (New York: Oxford University Press, 1982), 92, 103-05, 114; Rosalind Rosenberg, Divided Lives: American Women in the Twentieth Century (New York: Hill and Wang, 1992), 22-24, 50-52, 58-59; Kathryn Kish Sklar and Thomas Dublin, eds., Women and Power in American History: A Reader (Englewood Cliffs, N.J.: Prentice-Hall, 1991), vol. 1: 185-98; Nancy Woloch, Early American Women: A Documentary History, 1600-1900 (Belmont, Calif:: Wadsworth, 1992), 287-93, 337-39, 516-19. Also see the entries "Prostitution" in Eric Foner and John A. Garraty, eds., The Readers' Companion to American History (New York: HoughtonMifflin, 1991), 875-77; Elliott Gorn, Mary Kupiac Cayton, and Peter Williams, eds., Encyclopedia of American Social History (New York: Scribner, 1993), vol 3: 2157-65; Kenneth T. Jackson, ed., The Encyclopedia of New York City (New Haven, Conn.: Yale University Press, forthcoming); Neil Larry Shumsky, ed., American Cities and Suburbs: An Encyclopedia (New York: Garland, forthcoming).
}

\section{Continuing Problems with Archival Sources}

I should not, however, paint too rosy a picture. Many problems remain, even with these new sources and interpretations. I will discuss five here.

1. Who is speaking? Perhaps most vexing are the voices in these manuscripts. The persons speaking, recording, or describing the activity are usually investigators, judges, journalists, police, or law enforcement officials. Surprisingly, these sources provide the testimony of prostitutes infrequently. We rarely learn what specifically motivated women to engage in prostitution. Evidence points to economic factors, family problems, even personal desires. Seldom, however, do prostitutes tell their sides of the story. Even when testifying in court, these women present planned or scripted accounts of their activity, and the spontaneous outburst is infrequent. The few autobiographies of prostitutes, most of which do not appear until the twentieth century, are of questionable value. These are usually by prosperous madams, hardly representative of the common or occasional prostitute's experience. Some authors romanticize the entire practice of prostitution. Many accounts were probably edited to remove controversial and unsavory subjects. And most were published for profit, not to reveal truth. ${ }^{32}$

\footnotetext{
${ }^{32} \mathrm{Few}$ autobiographies of nineteenth-century prostitutes exist. The best-known is Nell Kimball, Nell Kimball: Her Life as an American Madam, edited by Stephen Longstreet (New York: Macmillan, 1970). Twentieth-century examples include Polly Adler, $A$ House Is Not a Home (New York: Rinehart, 1953); Sydney Biddle Barrows, Mayflower Madam (New York: Arbor House, 1985); Xavier Hollander, The Happy Hooker (New York: Dell, 1972); Sally Stanford, The Lady of the House (New York: G. P. Putnam's Sons, 1966). For a rare correspondence between a former prostitute and a reformer, see Ruth Rosen and Sue Davidson, eds., The Maimie Papers (Bloomington: Indiana University Press, 1977). An extensive listing can be found in Bullough and Bullough, Women and Prostitution, 363.
} 
2. Destruction of records. Cities have not preserved judicial and municipal records in any systematic way. New York City has the second-largest volume of records of any archives in the United States, but for decades these records sat forgotten, unorganized, and unused in old Tweed Courthouse. This is probably not uncommon. In many cities, similar records still languish in the custody of the court system; Baltimore and Philadelphia are examples. In Pittsburgh, court records have been preserved by the Archives of Industrial Society at the University of Pittsburgh because in the early 1970 s city officials, concluding they were not worth saving, were on the verge of destroying them. ${ }^{33}$ Chicago, the most studied city in the Americas, ${ }^{34}$ has no city archives; Mayor Richard M. Daley closed the Municipal Reference Library in 1993, hardly a sign that good times lie ahead. Fortunately, since her election as clerk of the Circuit Court of Cook County in 1988, Aurelia Pucinski has initiated efforts to preserve twentieth-century criminal records of Cook County. Previously, similar documents, including those covering the years from 1900 to 1927 , were destroyed as space was needed. ${ }^{35}$

\footnotetext{
${ }^{33}$ John Thompson to H-URBAN Urban History Discussion List, 9 July 1993 (in author's possession).

${ }^{34}$ Partly due to the numerous dissertations and theses sponsored by Louis Wirth, Ernest Burgess, and Robert Park in the sociology department at the University of Chicago between 1900 and 1940 (the socalled Chicago school of sociology), Chicago has been the subject of more study than any other North American city.

${ }^{35}$ The Municipal Reference Library in Chicago has been moved to the new Harold Washington Public Library, but it has yet to open. The Circuit Court of Cook County is currently the largest consolidated court system in the world. Its Archives Department holds over 300 cubic feet of felony, misdemeanor, and docket book records from 1871-1900, and 1927 to the present, in addition to naturalization records from 1871 to 1929 , and divorce, probate and chancery records. Some municipal court records from 1914 to 1926 were microfilmed in the 1950 s but remain unlabeled. The archives is currently completing a rough survey of the approximately 750 microfilms. The ar-
}

Public and private archives alike did not realize the value of many of these sources until recently. Only a few archives, for example, retained and preserved brothel guidebooks. The National Police Gazette (published from 1845 to 1933), the most widely read crime and sex publication of its time, is scattered among a variety of institutions. The American Periodical Series preserved the Gazette on microfilm but lacks issues between 1849 and $1866 .{ }^{36} \mathrm{Un}$ til an anonymous collector donated his collection of "flash", or "sporting" newspapers to the American Antiquarian Society in the late 1980 s, only scattered examples could be found. ${ }^{37}$ Many libraries and archives simply did not see any value in preserving such material. Still others, wittingly or not, followed policies of selfcensorship regarding issues of sexuality.

3. Lack of access. The third and related dilemma is the sheer volume and quantity of public and court records. In Philadelphia's City Archives, for example, the bills of indictment since 1800 measure approximately 230 cubic feet. In New York, the district attorney indictments from the Court of General Sessions from 1790 to 1879 amount to 647 cubic feet, or 1,294 boxes. Even more daunting are corresponding records for the twentieth century. From 1896 to 1965 , municipal courts in New York City produced 6,500 cubic feet of pa-

chives is located in Room 1113, Richard J. Daley Center, Chicago, Ill;; records are stored in the former Spiegel's warehouse at 23rd Street and Rockwell Avenue. State's attorney records since 1930 (which include grand jury proceedings) remain closed to the public. I am indebted to conversations with Phillip Costello for this information.

${ }^{36}$ The Gazette jumps from 4 September 1847 to 28 October 1848 to 21 April 1866 in the American Periodical Series, Number 2, Reel 1318.

${ }^{37}$ Significantly, the few examples of these newspapers I discovered were in various libel cases brought to trial in New York and found in the District Attorney Indictment Papers, Court of General Sessions, NYCMA. 
per, the equivalent of 13,000 boxes, or ten times the nineteenth-century figure. ${ }^{38}$

Some cities cannot salvage such records. In Chicago, for example, the Circuit Court Archives saves only a 3 percent random sample of misdemeanor cases older than ten years. Since 1970, such prosecutions have exceeded 300,000 annually; storage problems simply prevent preservation of the entire record group. ${ }^{39}$ Indeed, the uncataloged organization and sheer quantity of these and similar municipal records has discouraged historians from exploiting such materials. Yet these are the very records that reveal the most descriptive and precise information about urban street life and sexual behavior. For historians of the twentieth century investigating solicitation patterns of prostitutes, gambling, the evolution of male prostitution, the proliferation of drug subcultures, juvenile delinquency, urban violence, or the movement of certain kinds of low-level criminal activity, these are invaluable and unique sources. ${ }^{40}$

Future historians will regret the destruction of such records. Misdemeanor and criminal cases are the same sources that permitted a reinterpretation of the history not only of prostitution but of many other sexual behaviors as well. If storage of such data is unrealistic or impossible, historians

\footnotetext{
${ }^{38}$ These twentieth-century records - the closed case files of the New York district attorney-have not been processed but are available to researchers. The volume of holdings by the New York City Municipal Archives is enormous: approximately 30,000 cubic feet in the archives building at 31 Chambers Street, and another 60,000 cubic feet at its Brooklyn warehouse.

${ }^{39}$ The Circuit Court Archives maintains a sixty-year retention schedule for felony cases. Before 1960, felonies numbered under 10,000 annually; since 1980 , they have exceeded 30,000. Conversation with Phillip Costello, 15 February 1994.

${ }^{40}$ Misdemeanor cases in the Circuit Court of Cook County Archives include assault and battery, drug possession, fornication, gambling, inciting a riot, larceny, and obscenity. In addition to the 3 percent sample that is saved, archivists try to save additional cases they think may be of interest to future historians.
}

and archivists alike must develop new methods to preserve these invaluable records. ${ }^{41}$ One possible solution is computer scanning and imaging technology. By scanning documents designated for destruction, archives will save valuable space while creating a computer-accessible, primary database. Problems still plague this technology, especially regarding handwritten and pre-1900 typefaces. Nevertheless, typewritten and printed twentieth-century documents are scanned more easily than their older handwritten counterparts. The creation of such databases would preserve previously discarded documents and potentially would allow wider public access to them. At this moment, however, the technological difficulties and costs of scanning probably prevent immediate application..$^{42}$

4. Twentieth-century sources. American municipalities in the second half of the twentieth century have created a more detailed public record regarding the sex industry. Since 1971, for example, Nevada counties with fewer than 200,000 residents have enjoyed the authority to license prostitution. ${ }^{43}$

Similarly, since the U.S. Supreme Court accepted zoning as a way to control "adult entertainment" in 1976, numerous cities and counties have resorted to formal plan-

\footnotetext{
${ }^{41}$ For an environmental historian's analysis of a similar problem, see Samuel P. Hays, "Manuscripts for Recent History: A Proposal for a New Approach," Journal of American History 77 (1990): 208-16.

${ }^{42}$ Scanning technology allows the scanned document to be edited if necessary. Imaging technology reproduces the document as an exact image and does not permit editing. Handwritten documents and typefaces before 1900 still present numerous problems for scanners. See Stephen Hayes to H-URBAN Urban History Discussion List, 25 February 1994. Some observers also believe certain libraries and archives may prohibit all scanning and photocopying of documents in their collections in the future. See James Cook to H-URBAN Urban History Discussion List, 26 February 1994. (Both letters are in author's possession.)

${ }^{43}$ Elizabeth Vorenberg and James Vorenberg, “" 'The Biggest Pimps of All': Prostitution and Some Facts of Life," Atlantic (January 1977): 27-28.
} 
ning mechanisms to organize prostitution. Detroit, Boston, Dallas, Prince George's County in Maryland, Fairfax County in Virginia, Marion County in Indiana, Santa Monica and Los Angeles in California are only a few of the governments that resorted to such methods between 1972 and 1977 . Although these sources frequently fail to document the direct words and experiences of sex-industry workers themselves, they reveal considerably more about the dynamics of the enterprise than do the earlier records. In the past quarter-century, cities have produced a more descriptive and voluminous public chronicle concerning efforts to regulate, organize, or suppress prostitution than in any other period in American urban history. ${ }^{44}$

5. Privacy issues. The fifth and final problem concerns issues of privacy. Most archives have developed policies to balance the needs of researchers and the privacy rights of the individuals and their families mentioned in archival collections. The historian and archivist Judith Schwarz has shown how problematic this can be when dealing with questions of sexuality. Records that directly relate to the work of an institution or person are easy to classify as publicly available. Materials that interest the historian of sexuality, however, are more often categorized as private or personal. Records describing personal habits - daily schedules, shopping or purchase receipts, private letters-may embarrass some institutions. Such materials are often earmarked for destruction before they are deposited in archival collections. Historians of sexuality are then confronted with the ongoing problem of analyzing the si-

${ }^{44}$ See Young, Mayor of Detroit, et al. v. American Mini Theaters, Inc., et al., 427 U.S. 50 (1975); Fredric A. Strom, Zoning Control of Sex Businesses: The Zoning Approach to Controlling Adult Entertainment (New York: C. Boardman, 1977). I am indebted to Guy Louis Rocha of the Nevada State Library and Archives for discussions of this issue. lences created by such censorship. ${ }^{45}$ Ultimately, archivists need to strive for open access while preserving the privacy of living interests and protecting the interests of donating institutions. ${ }^{46}$

This question is even more problematic with public records. As local government agencies release (or even discard) records they no longer need to archive, researchers often have access to information that might be deemed private or restricted in certain nonpublic archives. The New York State Archives, for example, does not permit researchers to cite names found in certain record groups. Others, such as the New York City Municipal Archives, negotiate a period for public release with the relevant municipal agency, and they then require proof of a "legitimate" research, historical, or law enforcement objective to gain access to such records. ${ }^{47}$ Although this sounds like a clear-cut policy, there are considerable gray areas. For example, district attorney records frequently include confidential and speculative memoranda, investigative files, and other prosecutorial materials that were not part of the original public record. These records often mention individuals directly and indirectly connected to a case and often name victims of crimes who wish to have their privacy protected. Should client lists of prominent madams and prostitutes, for example, be considered part of the public record, and, if so, how can one test their authenticity? Should the names of "suspected" prostitutes found in police records (including

\footnotetext{
${ }^{45}$ For more on this issue of silences in archival collections, see John D. Wrathall, "Provence as Text: Reading the Silences Around Sexuality in Manuscript Collections," Journal of American History 79 (June 1992): 165-78.

${ }^{46}$ Judith Schwarz, "The Archivist's Balancing Act: Helping Researchers While Protecting Individual Privacy," Journal of American History 79 (1992): 179 89.

${ }^{47}$ Conversation with Kenneth Cobb, director, New York City Municipal Archives and Records Center, July 1993.
} 
those never convicted of such a charge) be available? Should cases of criminal rape, including the names of victims, be opened for public inspection? In one sense, such records are "really private and/or confidential" and should not be made public. ${ }^{48}$ But the bias of law enforcement is contradictory-female prostitutes are prosecuted and male clients are not; poor streetwalkers are convicted more often than wealthy madams are. These inconsistencies are manifested not only in what records are saved but also in which are made available to the public.

The initial and surface problem with such records is that they are criminal registers and thus public records. But what is a "public record"? Do criminal investigations with undocumented memos, printed hearsay, or outright lies that violate the privacy rights of an individual (to say nothing of libel laws) deserve to become part of the public record? ${ }^{49}$ Indeed, in the early twentieth century, investigators from private reform groups and the New York police claimed, in their private correspondence

\footnotetext{
${ }^{48} \mathrm{New}$ York district attorney records, years after a case has been completed and deposited in the Municipal Archives, are sometimes found to contain secret grand jury testimony that was originally intended to be a sealed record.

${ }^{49}$ For another example, see the use of the Cook County medical examiner's records on abortion cases in Leslie J. Reagan, "“About to Meet Her Maker': Women, Doctors, Dying Declarations, and the State's Investigation of Abortion, Chicago, 1867-1940," Journal of American History 77 (March 1991): 124064.
}

and reports, that such prominent public figures as Timothy "Big Tim" Sullivan, a Tammany Hall ward boss, and the investment banker J. Pierpont Morgan frequented prostitutes or maintained mistresses..$^{50}$ Just as much as historians, archivists quite likely will be directly confronted by questions about the boundaries of acceptable behavior and who determines those boundaries. When the rights of the research community conflict with the rights of the individual, whose culture, value system, or moral guideposts will prevail?

More than ever, historians and archivists need to develop new and improved networks of cooperation. ${ }^{51}$ The new social history of the past three decades issued an invitation to historians of sexuality: to make previously invisible topics and individuals visible. Much of this literature would have been impossible to conceive and write without court, county, and municipal records. Examinations of twentiethcentury sexuality will be considerably impaired if historians and archivists fail to find ways to preserve these historical treasures.

\footnotetext{
${ }^{50}$ On Morgan, see Handwritten Report on Avenel Hotel, 8 July 1913, Box 28, Committee of Fourteen Papers, New York Public Library. On Sullivan, see Complaints and Investigations, Police Department, Minutes of 1 August 1908, Box MGB-120, Mayors' Papers, NYCMA.

${ }^{51} \mathrm{On}$ the need for greater cooperation between historians and archivists, see Page Putnam Miller and David Thelen, "Reconnecting Historians and Archivists," Chronicle of Higher Education, 8 December 1993, p. B3.
} 